The exponential formula of Biot was first tried. Log. $\mathrm{F}=a+$ $b a^{\mathrm{x}}+c^{\mathrm{x}}$, in which $\mathrm{F}$ is the pressure, $x$ the temperature plus a constant. In equation $(F)$ which relates to temperatures above $100^{\circ}$, $x=\mathrm{T}-100$, in (H) $x=\mathrm{T}+20$, and applies to all temperatures. M. Roche proposed the formula $F=a \frac{\mathrm{x}}{a+\mathrm{mx}}$ founded on theoretical considerations and represented by $\mathbf{K}$. The deviation here being greater, the exponential formula was adopted, and by it the common table for the pressure of steam was computed. It will be noticed that certain irregularities are common to all, for instance, at $150^{\circ}$ and $200^{\circ}$. These were evidently due to the impossibility of constructing graphically a perfectly smooth curve. As, moreover, the deviation in many cases amounts to one centimetre we see that even the third place of decimals is sometimes doubtful.

The above examples show that it is perfectly possible thus to render obvious the errors even in the most accurate series of experiments, while from a curve we are able to judge with far more cer. tainty of the nature of the errors and the best means of diminishing them, than it is possible to do from the numerical results.

Mass. Inst. of Technology, Nov. 1st, 1870.

\title{
ON THE COMPOSITION OF THE SHELL OF THE LINGULA PYRAMIDATA.
}

By Charlers P. Willams, Profegoor of Chemiatry, Delaware College.

Is 1854, Dr. T. Sterry Hunt first showed * that the shells of the Lingulæ were composed mainly of calcic-phosphate, and that, at least so far as their cinereal ingredients were concerned, they had a com. position closely approximating to that of the bones of the vertebrata. The probable relation of fossil species of this genus to the phosphatic nodules found in the oldest members of the Silurian rocks of Canada, was also pointed out by the same chemist. Recently, Prof. W. C. Kerr, Geologist to North Carolina, has ascribed $\dagger$ the origin of the material of the interesting and commercially im. portant deposits of South Carolina, to an existing species of same genus. This species is the Lingula Pyramidata, now living in the

* Am. Jour. Science (2) XVII, page 235.

$\dagger$ In a paper read before the American Association, at its August (1870) meet. Ing-an abstract being given in the American Chemist, Nov, , 1870, p. 180. 
shoals along the coasts of North and South Carolina, and having, according to the last named observer, a habitat at the precise level Ashley phosphates.

Some months since, through the kindness of Mr. Geo. T. Lewis, of Philadelphia, I received several specimens of this interesting brachiapod, and have completed two analyses of a sample of their shells. The specimens were from Beaufort Harbor, N. C. The average weight of the detached shells and adhering membrane, in their fresh state, was $\cdot 0436$ grammes. The samples were carefully dried at $100^{\circ} \mathrm{C}$, and the analyses were conducted in the following manner: The organic matters were estimated by incineration and subsequent moistening with carbonate of ammonia and ignition. The hydrochloric acid solution was treated with ammonia and acetic acid, for the precipitation of the ferric phosphate and fluo. ride of calcium ; in the filtrate acidulated with acetic acid, the lime was thrown down as an oxalate, but subsequently converted into and weighed as a sulphate; the magnesian phosphate precipitated in the filtrate by the addition of ammonia, and finally the remaining phosphoric acid separated by adding the magnesian solution. This last precipitate was dissolved, and re-precipitated and weighed in the usual manner. The first precipitate, by ammonia and acetic acid, was analyzed for fluoride of calcium, and separate samples were taken for the carbonic acid and for the sulphate of lime, etc., soluble in water. Annexed are the results:

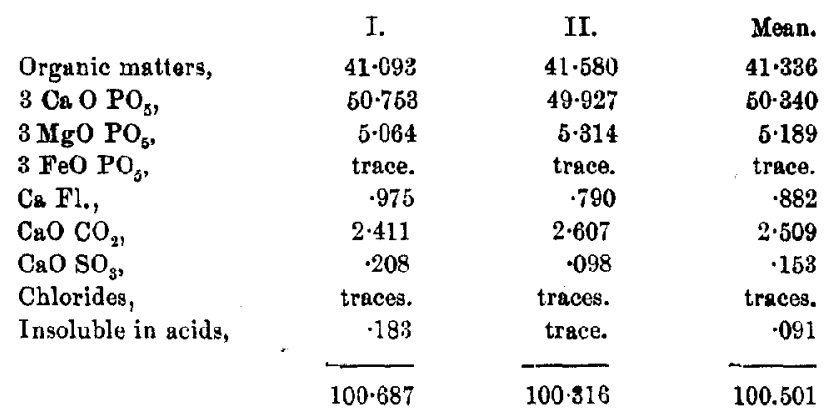

In Dr. Hunt's analysis of a specimen of the Lingula ovalis, 0.186 grammes lost by calcination 0.072 grammes, which corresponds to 39.24 per cent. of organic matters. The ash gave him 85.79 per cent. of tri-calcic phosphate, which, calculated to the original shell, would give 52.12 per cent,-a result not differing materially from 
that obtained by myself for the Lingula pyramidata, and both showing a close approximation in the shell of this brachipod to that of human bonc. No estimation was made of fluoride of calcium by Hunt, but in the species analyzed by me the relation existing in apatite, between this substance and the phosphate of lime, was not obtained.

From among the many complete analyses of the Charleston phosphate $I$ have from time to time made, the following $(I)$ is selected for comparison with the result (II) obtained by Hunt, in an analysis of a rounded mass, of a yellowish color, from the Chazy limestone of Hawkesbury, containing fragments of a fossil Lingula, and which had probably resulted from this:

I.

$60 \cdot 47$

$3 \mathrm{CaO} \mathrm{PO}_{5}$,

$3 \mathrm{Mg} O \mathrm{PO}_{5}$.

$\mathrm{Al}_{2} \mathrm{O}+\mathrm{Fe}_{2} \mathrm{O}_{3}$,

$\mathrm{Ca} \mathrm{Fl}$,

$\mathrm{CaO} \mathrm{CO}{ }_{2}$,

$\mathrm{CaO} \mathrm{SO}_{3}$,

$\mathrm{NaCl}$,

Organic matters,

Insoluble Silicious Matters,
$2 \cdot 38$

$2 \cdot 08$

.50

8-34

$2 \cdot 89$

.62

8.56

$12 \cdot 27$
II.

44.71

$\mathrm{MgOCO}, \quad 476$

860

$6 \cdot 60$

$5 \cdot 00$

$27 \cdot 96$

97.56

These results, compared with the composition of the possible sources of the materials-the Lingula-show that in the process of fossilization the phosphate of lime is not concentrated, but is rather diminished, it may be, either by solution through the agency of the decomposition of the nitrogenous organic matters of the recent specimens, or by decomposition through carbonic acid and subsequent solution. S. P. Sharples, * in commenting upon his analyses of rocks, bearing some analogy to the Charleston phosphates, but obtained by dredging from the Gulf Stream, suggests this same change in the direction of loss of phosphate of lime, and states that the more recent the bone the more abundant the phosphoric acid. Admitting this, the diminished amount of calcic-phosphate in the Charleston material cannot be regarded as militating against the view. that its origin may be due to the comminution, alteration and agglomeration of the shells of the Lingula now inhabiting the shoal waters of the coast of Nortl and South Carolina The persistance of these

$\because A m$. Jour. Sciences, Mrarch, 1871. 
brachipods through all geological periods, from the Potsdam sand. stone upwards, in connection with the composition of their testaceous coverings, may give them a significance in the genesis of phosphatic nodules and minerals, not now admitted. They may at least sug. gest the inquiry in how far other recent deposits of the so-called phosphatic guanos, such as are found on Navassa, Swan, and Sombrero islands may originate from the remains of other Molluscous animals with shells of a composition similar to the Lingulæ.

Newark, Delaware, March 1:, 1871.

\section{ON THE USE OF HYDRAULIC MORTAR.}

[Translated from "Die hydraulischen Mörtel" of Dr. W. Michaëlis, for the Journal of the Franklin Institute.]

By ADOLPa OTT

In is the peculiarity of all hydraulic mortar, that it hardens under the influence of water, and becomes almost wholly insoluble in the same; it is therefore necessary to make use of it wherever a construction is exposed to the destructive agency of that element, either continually or from time to time.

Hence, this mortar is one of the most essential requisites for all bydraulic constructions, as it would be impossible to erect a durable building under water without baving recourse to this cement, un. less the use of mortar be abstained from altogether, and large and carefully prepared building stone used instead, which would not require any cementing whatever.

The enormous cost and the diffeulties of the latter method would most undoubtedly reduce the number of such constructions to a minimum, and when, for instance, we now see imposing lighthouses boldly defying the threatening pressure of the waves, the mariner might be exposed to all the dangers of the coast without a warning signal or a guiding beacon; where splendid ports, with massive docks and bulwarks, most effectually protect trade and commerce against the indomitable nature of a powerful element, we would probably find no trace of the lively intercourse and international commerce which animate our principal seaports, had not human skill and ingenuity found means to replace by art what nature has either refused or granted only at a few exceptional places.

And even at the latter it is reserved to the hand of man to give

Vol. LX.-ThIRD SHFirs.-No. 4.-APHL, 1871. 